ISSN 1678-3921

Journal homepage: www.embrapa.br/pab

For manuscript submission and journal contents, access: www.scielo.br/pab

\section{Performance of cobia grown in brackish water and fed with different feeding rates}

\begin{abstract}
The objective of this work was to evaluate different feeding rates on the productive performance of cobia (Rachycentron canadum) grown in brackish waters. For the experiment, 1,600 juveniles were distributed in 16 enclosures installed in an estuarine pond. Four different feeding rates were evaluated: $1,3,5$, and $7 \%$ live weight (LW) per day. The following performance parameters were assessed: survival, final biomass, specific growth rate, daily weight gain, apparent feed conversion, protein efficiency rate, lipid efficiency rate, and hepatosomatic index. Survival was greater than $80 \%$ at all feeding rates. The most efficient feed conversion rate was obtained with the feeding rate of $5 \% \mathrm{LW}$ per day, which also resulted in better values for the hepatosomatic index. The rate of $5 \% \mathrm{LW}$ per day provides a better productive performance for cobia in brackish waters.
\end{abstract}

Index terms: Rachycentron canadum, feeding management, hepatosomatic index, mariculture, shrimp culture.

\section{Desempenho de bijupirá criado em águas salobras e alimentado com diferentes níveis de arraçoamento}

Resumo - O objetivo deste trabalho foi avaliar diferentes taxas de
arraçoamento no desempenho produtivo de bijupirá (Rachycentron canadum)
criado em águas salobras. Para o experimento, 1.600 juvenis foram
distribuídos em 16 cercados instalados em viveiro, em área estuarina. Foram
avaliados quatro diferentes níveis de arraçoamento: $1,3,5$ e $7 \%$ do peso
vivo (PV) por dia. Avaliaram-se os seguintes parâmetros de desempenho:
sobrevivência, biomassa final, taxa de crescimento específico, ganho de
peso diário, conversão alimentar aparente, taxa de eficiência proteica, taxa
de eficiência lipídica e índice hepatossomático. A sobrevivência foi superior
a $80 \%$ em todos os níveis de arraçoamento. A conversão alimentar aparente
mais eficiente foi obtida com a taxa de arraçoamento de $5 \%$ do PV por dia,
que também resultou em melhores valores para o índice hepatossomático. A
taxa de $5 \%$ do PV por dia proporciona melhor desempenho produtivo para o
bijupirá em águas salobras.

Termos para indexação: Rachycentron canadum, manejo alimentar, índice hepatossomático, maricultura, carcinicultura.

\section{Introduction}

Cobia, Rachycentron canadum (Linnaeus, 1766), is the most commercially produced marine fish species in Brazil due to its high growth rate of up to $6 \mathrm{~kg}$ in one year of captivity, good resistance to handling, and efficiency in converting feed, besides being greatly 
demanded by the market (Benetti et al., 2010; Kerber et al., 2011). Because of these factors, farming technology for the species is also being rapidly developed in China and Taiwan (Sampaio et al., 2010). Since cobia can be found in estuarine areas (Ditty \& Shaw, 1992), the possibility of their cultivation in ponds supplied by waters with salinity between 5 and $25 \mathrm{~g} \mathrm{~L}^{-1}$ has been studied (Resley et al., 2006). Brazil has more than 22,000 hectares of nurseries in estuarine areas currently used for the cultivation of the whiteleg shrimp Litopenaeus vannamei, and the use of marine fish in these environments could allow a new alternative form of production and income for this productive sector (Sanches et al., 2014b).

As a basic condition for the cultivation of a species, the feeding protocol aims to improve productive performance and survival, reduce feed conversion rate and batch heterogeneity, and simultaneously contribute to minimum food waste, maximizing the profit of the enterprise (Aydin et al., 2011; Al Zahrani et al., 2013). However, the lack of information on the correct quantity of food to be supplied to fish can lead to excesses, which cause deterioration of water quality, increasing the amount of effluents released into the environment and decreasing the environmental sustainability of fish farming (Salama, 2008; Abbas \& Siddiqui, 2009). The feeding rate, expressed as a percentage of live weight, represents the total amount of feed to be supplied to fish daily (Santos et al., 2015). Considering that the cost of producing aquatic organisms is significantly affected by feed consumption, studies that can define appropriate feeding rates for the different age groups of these organisms become essential for the establishment of good management practices.

The few studies on feeding rates in tropical marine fish species used from 2 to $6 \%$ live weight per day for fish up to $250 \mathrm{~g}$ both for experiments and commercial production in net tanks (Benetti et al., 2010; Ramos et al., 2012; Sanches et al., 2014a). Cunha et al. (2013) evaluated the effect of feeding rates on the growth of plata pompano (Trachinotus marginatus), concluding that a rate of $8 \%$ of the total weight per day offered to \pm 4.8 -g fish resulted in an improved productive performance. It was observed that the use of high rates caused a higher feed conversion, whereas reduced rates negatively affected growth. However, when evaluating 2.0-g samples of the camouflage grouper, Epinephelus polyphekadion, in Asia, Al Zahrani et al. (2013) found that the rate of $1.2 \%$ provided the best results. For specimens of fat snook (Centropomus paralellus), with a mean weight of $9.8 \mathrm{~g}$, a $3 \%$ rate provided a better productive performance (Oliveira et al., 2013). The obtained results are indicative that the used feeding rates of 2 to $6 \%$ may be inadequate to reach the zootechnical potential of cobia raised in nurseries with low salinity waters.

The objective of this work was to evaluate different feeding rates on the productive performance of cobia grown in brackish waters.

\section{Materials and Methods}

The study was carried out in a nursery of the Lusomar Maricultura Ltda. company, in the municipality of Jandaíra, in the state of Bahia, Brazil. The nursery had a sandy bottom, dimensions of $110 \times 40 \mathrm{~m}$, and an average depth of $1.5 \mathrm{~m}$. The tanks received brackish water from the estuary through pumping and screen filtration of 1,000 microns. In the nursery, 16 fences were installed, made of a nylon fabric covered with polyvinyl chloride (PVC) and a 17x12-mm mesh, totaling an area of 44.17 $\mathrm{m}^{2}$ with a diameter of $7.5 \mathrm{~m}$ and a height of $2.4 \mathrm{~m}$, fixed on wooden stakes and 8-mm polyamide ropes. The enclosures were distributed symmetrically in the longitudinal and transverse measurements so that they all had the same condition of water circulation, and they were numbered from 1 to 16 for further distribution of treatments. The experiment was conducted in a completely randomized design.

A total of 1,600 juveniles of cobia $(18.3 \pm 0.9 \mathrm{~g}$ and $15.2 \pm 0.8 \mathrm{~cm}$ total length) obtained by breeding in captivity were used. The fish - 100 individuals per enclosure - were divided into four treatments, with four replicates each, and subjected to four feeding rates: $1,3,5$, and $7 \% \mathrm{LW}$ per day. Before entering the system, all fish were weighed, measured, and passed through a freshwater bath for $5 \mathrm{~min}$ to eliminate any ectoparasites (Kerber et al., 2011). The experiments were approved by the committee of ethics in animal experimentation of Instituto de Pesca (001/2017).

The fish were fed the Pirá Crescimento QS commercial feed (Mogiana Alimentos S.A., Campinas, SP, Brazil), with $45 \%$ brute protein and $9.5 \%$ ethereal extract, the manufacturer's recommended centesimal composition. The feed was supplied twice daily at 8:00 a.m. and 4:00 p.m., six days a week, from Monday to Saturday, in amounts varying according to the treatments, from 1 to $7 \%$ of the total weight of each enclosure. It should be pointed out that the experiment was carried out during the hottest period of the year, from November to March.

The water variables were monitored throughout the experimental period. Temperature, $\mathrm{pH}$, and dissolved oxygen were determined with the HI9828 oximeter (Hanna Brasil, Barueri, SP, Brazil). In addition, total ammonia and alkalinity were obtained 
by the colorimetric method, using the Tetra TestStrips Ammonia and Tetra Test KH kits (Tetra Werke, Melle, Germany), respectively; salinity, with the F-3000 optical refractometer (Bernaqua, Bernauer Aquacultura, Indaial, SC, Brazil); and transparency, with a Secchi disk (Alfakit, Florianópolis, SC, Brazil).

Biometrics were performed in all animals before and at the end of the experimental period, every 30 days and at 120 days, respectively, using an ichthyometer and a digital electronic scale with an accuracy of 0.01 g. For the biometric analysis, the fish were anesthetized with benzocaine ( $0.05 \mathrm{~g} \mathrm{~L}^{-1}$ water) and then measured and weighed individually. After each biometry, the increment of total weight was considered to define the new quantity of food to be offered.

From the values for fish total length $(\mathrm{cm})$, weight (g), feed intake (grams per day), and mortality records, the following performance parameters were evaluated: survival, as [(live fish/ initial number of individuals) $x$ 100]; final biomass, as number of fish at the end of the experiment/the final total weight of fish in grams; specific growth rate, as [((ln of the final weight - ln of the initial weight)/number of days of the experimental period) x 100]; daily weight gain, as [(final weight initial weight)/number of days of the experimental period]; feed consumed, as [(total amount of food consumed in the period/final number of fish]; feed conversion rate, as [(total amount of feed consumed in the period/weight gain during the experimental period); lipid efficiency rate, as weight gain/ethereal extract consumed; and protein efficiency rate, as weight gain/gross protein intake.

At the end of the experiment, 8 fish from each enclosure, totaling 128 fish, were desensitized by heat shock, individually weighed, and dissected in the abdominal region for the removal of their liver, which was weighed to calculate the hepatosomatic index (HIS, \%) by: HSI $=\mathrm{P}_{\mathrm{t}} /\left(\mathrm{P}_{\mathrm{fx}} 100\right)$, where $\mathrm{P}_{\mathrm{t}}$ is the total weight and $\mathrm{P}_{\mathrm{f}}$ is the liver weight.

The obtained results were subjected to the analyses of variance and regression, at 5\% probability, using the Saeg statistical package (Universidade Federal de Viçosa, Viçosa, MG, Brazil).

\section{Results and Discussion}

The values obtained for the monitored environmental variables were: $31.4 \pm 1.1^{\circ} \mathrm{C}$ for temperature, $21.5 \pm 4.9$ for salinity, $6.9 \pm 0.2 \mathrm{mg} \mathrm{L}^{-1}$ for dissolved oxygen, $0.2 \pm 0.1$ $\mathrm{mg} \mathrm{L}^{-1}$ for total ammonia, 7.8 \pm 0.3 for $\mathrm{pH}, 103.0 \pm 7.1$ $\mathrm{mg} \mathrm{CaCO}_{3} \mathrm{~L}^{-1}$ for alkalinity, and $63.4 \pm 8.3 \mathrm{~cm}$ for transparency, all within the range considered adequate for the species (Shaffer \& Nakamura, 1989). Survival did not differ significantly between treatments: $79.5 \pm 2.1 \%$ for $1 \%$ LW per day, $85.33 .6 \%$ for $3 \% \mathrm{LW}$ per day, $81.3 \pm 5.9 \%$ for $5 \%$ LW per day, and $76.0 \pm 9.4 \%$ for $7 \%$ LW per day. Cobia showed to be resistant to the conditions of cultivation in brackish water, besides having high survival rates of 80 and $75 \%$, respectively, in previous studies in laboratory conditions (Resley et al., 2006) and in net cages (Benetti et al., 2010).

Although the productivity of a cultivation system can be measured by the final biomass produced, daily feeding rates reflected positively on the performance of cobia through a nonlinear relationship. Considering this, it was possible to observe that the final biomass increased with higher daily feeding rates up to a certain rate, after which it was significantly lower than that of the other treatments (Figure 1). By the derivative of the equation, the highest final biomass was obtained at the point where the curve presented the value corresponding to $4.95 \%$ of the daily feeding rate.

The specific growth rate (SGR) may be an indicative of productive performance. As the feeding rate was increased, the SGR was significantly higher: $1.4 \pm 1.3 \%$ for $1 \% \mathrm{LW}$ per day, $1.7 \pm 1.2 \%$ for $3 \% \mathrm{LW}$ per day, $2.1 \pm 0.2$ for $5 \% \mathrm{LW}$ per day, and $2.4 \pm 0.3 \%$ for $7 \% \mathrm{LW}$ per day. Al Zahrani et al. (2013) studied the feeding rate of juvenile Asian groupers weighing $2.1 \mathrm{~g}$ and found that,

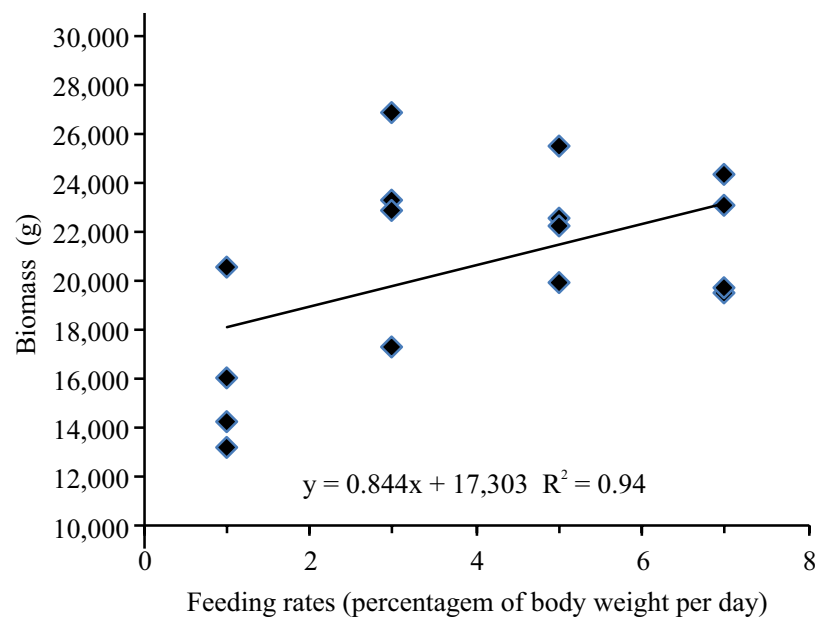

Figure 1. Relationship between final biomass and different feeding rates for cobia (Rachycentron canadum) cultivated in brackish waters. Line represents regression tendency. Final biomass was obtained by number of fish at the end of the experiment/final total weight of fish in grams. 
for Epinephelus polyphekadion, the SGR was higher in treatments with higher feeding rates of $4 \%$. When evaluating the initial growth stage of another grouper species, the dusky grouper Epinephelus marginatus, with an initial weight of $5.5 \mathrm{~g}$, using $40 \%$ brute protein and $8 \%$ ether extract, Ramos et al. (2012) obtained a SGR of 1.68 for a feeding rate of 5\%. Similar results were reported for cobia, for which the rate of $7 \%$ provided a higher SGR than that of 3\% (Sun et al., 2016). In the present study, increasing the feeding rate increased the SGR; however, this parameter alone cannot be used as an indicator of performance.

Regarding daily weight gain, a significant difference was observed among treatments (Figure 2). The obtained results fit a linear function, with higher values as the feeding rate increased: $1.38 \pm 0.36 \mathrm{~g}$ for $1 \% \mathrm{LW}$ per day, $1.89 \pm 0.31 \mathrm{~g}$ for $3 \% \mathrm{LW}$ per day, $2.01 \pm 0.19 \mathrm{~g}$ for $5 \% \mathrm{LW}$ per day, and $2.08 \pm 0.29 \mathrm{~g}$ for $7 \%$ LW per day. Other authors also observed that the daily weight gain of the fish was directly proportional to the rate of feed used (Nhu et al., 2011; Al Zahrani et al., 2013; Oliveira et al., 2013). In Brazil, cobias fed with a feeding rate of $3 \%$, at different feeding frequencies, presented a daily weight gain of 1.48 to $1.67 \mathrm{~g}$ (Costa-Bomfim et al., 2014). It should be noted that some authors do not adopt feeding rates, preferring the principle of apparent satiety when supplying food,

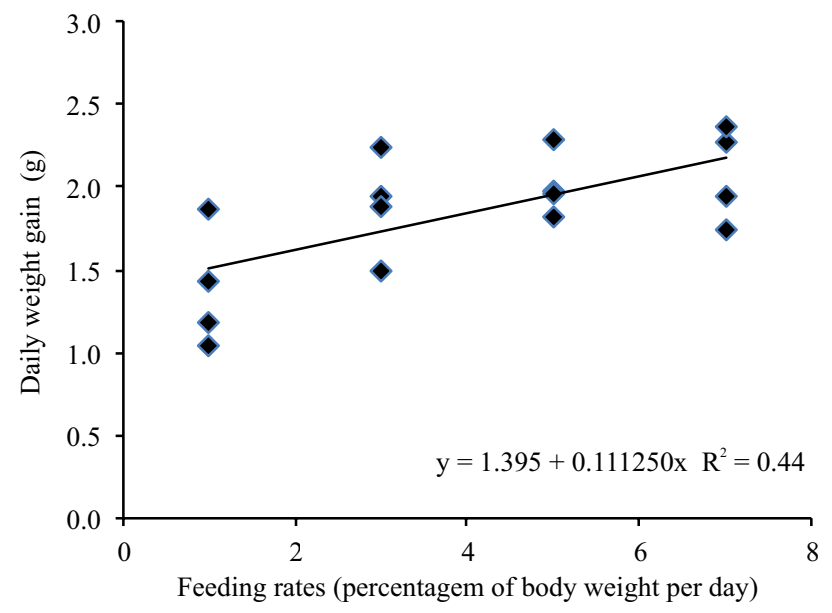

Figure 2. Relationship between daily weight gain and different feeding rates for cobia (Rachycentron canadum) cultured in brackish waters. Line represents regression tendency. Daily weight gain was obtained by [(final weight - initial weight)/number of days of the experimental period]. which leads to great subjectivity, making it difficult to compare results. Moreira et al. (2015) found that cobias reared in net cages showed a daily gain of 1.4 to 2.5 $\mathrm{g}$ and a feed conversion rate ranging from 2.3 to 3.2 ; however, fish were fed to apparent satiety. Considering these results, the weight gain of 1.38 to $2.08 \mathrm{~g}$ of cobias cultivated in brackish water was superior to those of others species. When cultivating fat snook (Centropomus parallelus) in net cages, Ostini et al. (2007) obtained a daily weight gain of $0.62 \mathrm{~g}$ per day for fingerlings weighing $32 \mathrm{~g}$. However, Sanches et al. (2011) reported a daily weight gain of $0.41 \mathrm{~g}$ per day, in a salt-water recirculation system, for fish with an average initial weight of $35 \mathrm{~g}$.

The efficiency of feed use, which can be measured by the feed conversion rate, is another important performance parameter. In the present study, the average apparent feed intake increased as the feed supply increased (Figure 3), which could suggest the need to increase the supply of feed for a higher consumption and better performance of animals. However, feed conversion rate worsened with the increase in the percentage of feed supplied, which shows that, despite increasing consumption and weight gain, the increase in daily feeding rates leads to a poorer efficiency in the use of the diet, with undeniable financial and environmental damages.

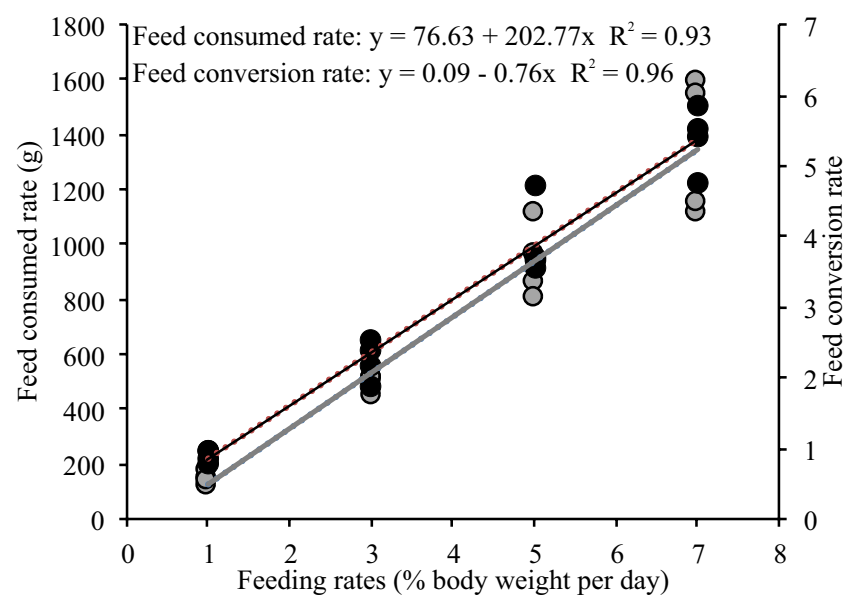

Figure 3. Relationship between feed consumed rate (gray) and feed conversion rate (black) and different feeding rates for cobia (Rachycentron canadum) cultured in brackish waters. Lines represent regression tendency. 
When evaluating the different feeding rates for fat snook, Oliveira et al. (2013) found that weight gain, final biomass, apparent food conversion, and SGR were influenced by different feeding rates of 3 and $6 \% \mathrm{LW}$ per day. According to the authors, the weight gain and the final total weight of the fish that received daily feeding rates of 3\% were significantly higher than those receiving $6 \%$, as observed in the present study. However, the most efficient feed conversion was obtained at the feeding rate of $3 \%$, and the feed conversion of 2.5 at the highest feeding rates would economically hinder fish production. The same trend can be observed for marine fish. For Florida pompanos (Trachinotus carolinus) 4.8-g juveniles, the adoption of feeding rates lower than $4 \%$ resulted in worse growth and increased aggressiveness, besides not being adequate for the fish to meet their basal energy needs and still express higher growth potentials. Furthermore, the use of high rates, above $8 \%$, led to a worsening of feed conversion (Cunha et al., 2013). In the present study, the low feeding rates resulted in a low productive performance, whereas rates above $5 \%$ caused a significant worsening of feed conversion.

Although the best production of final total weight was obtained with the supply of $4.91 \%$ feed per day, feed consumption and, consequently, the cost of production, increased linearly, being lower for the lower feeding rates. This may be justified by the better efficiency of dietary protein and lipid use at the lower supply levels (Figure 4). Both lipid and protein efficiency were higher in the lower feeding rate of $1 \%$ LW, reducing with the increase in feed supply.

The values found for the HSI differed significantly between treatments (Figure 5). There was a reduction in the HSI between feeding rates of 1 and $3 \% \mathrm{LW}$, which did not differ from each other but differed from the treatments with 5 and $7 \%$ LW, which presented the highest values for the HSI. This index expresses hepatic growth due to metabolic demands such as the need to eliminate residues of nutritional origin, which could be related to the overconsumption of ration as the food supply was increased. Although the fat deposition in the liver was not measured, the reduction in lipid and protein efficiency associated with the increase in diet supply, as well as the increase in the HSI, suggests that there was a greater accumulation of fat in the liver as the supply of feed increased (Sanches et al., 2019).
In a previous work, the HSI also showed high values, which ranged from 0.70 to 1.30 , for the dusky grouper, indicating that the addition of fish oil to the feed caused a high accumulation of fat in the liver (Sanches et al., 2014a). The higher HSI may be the result of a higher fat deposition in the liver, attributed to a metabolic disorder or to an increase in the gluconeogenesis

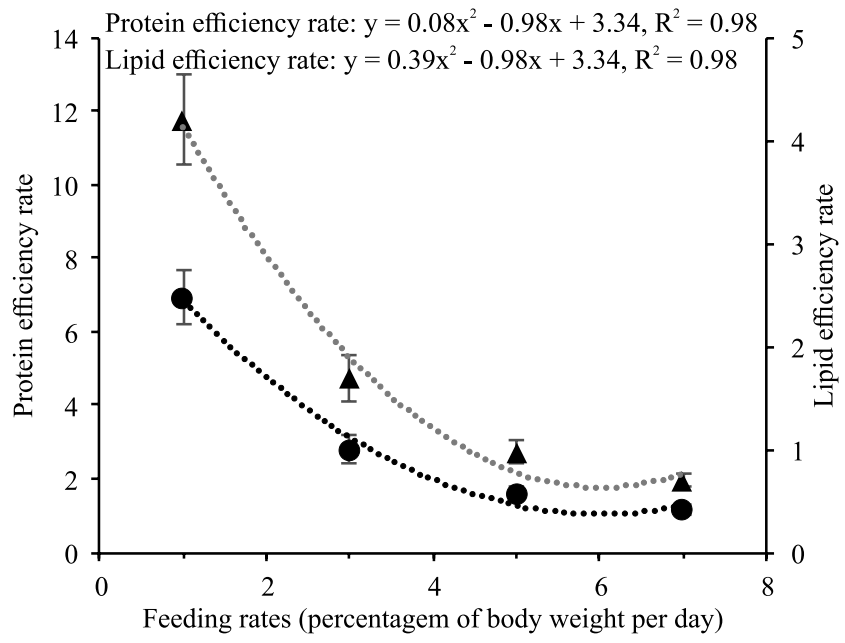

Figure 4. Effects of different feeding rates on the protein efficiency rate (circle) and lipid efficiency rate (triangle) of cobia (Rachycentron canadum) cultured in brackish waters. Lines represent regression tendency.

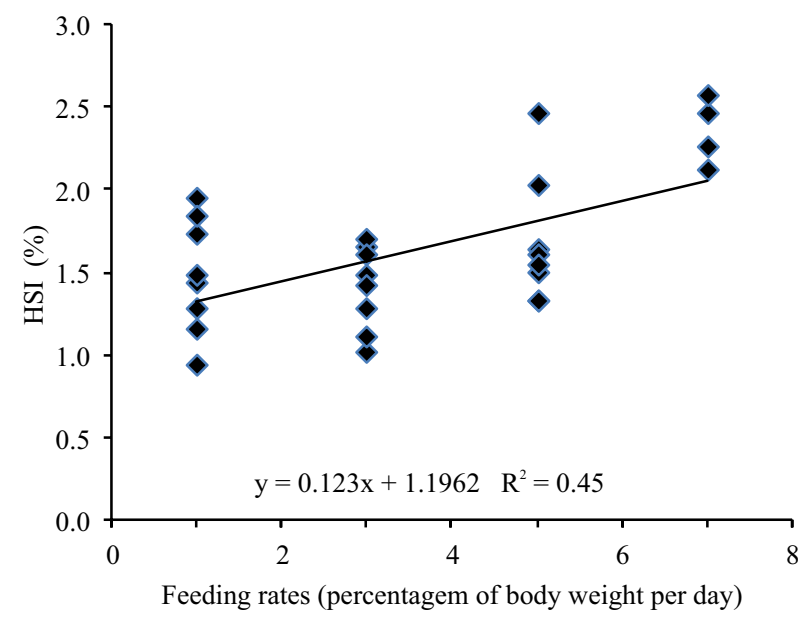

Figure 5. Relationship between the hepatosomatic index (HSI) and different feeding rates for cobia (Rachycentron canadum) cultured in brackish waters. Line represents regression tendency. 
process by stressors, such as the need to metabolize high lipid levels (Fabregat et al., 2011). Kaushik et al. (2004) and Fabregat et al. (2011) also observed increases in the HSI resulting from lipid deposition in the liver due to the hyperplasia of the organ, which suffered an overload because of a nutritional imbalance.

The present study showed the importance of establishing an adequate feeding rate for cultivating cobias in brackish waters. This opens the possibility of cultivating this fish in estuarine nurseries, adding an alternative species for enterprises dedicated only to shrimp farming.

\section{Conclusion}

The feeding rate of 5\% body weight per day provides better productive performance for cobia (Rachycentron canadum) in brackish waters.

\section{Acknowledgments}

To Coordenação de Aperfeiçoamento de Pessoal de Nível Superior (Capes, grant number 88882.317475), for financial support.

\section{References}

ABBAS, G.; SIDDIQUI, P.J.A. Effects of different feeding level on the growth, feed efficiency and body composition of juvenile mangrove red snapper, Lutjanus argentimaculatus (Forsskal 1775). Aquaculture Research, v.40, p.781-789, 2009. DOI: https://doi.org/10.1111/j.1365-2109.2008.02161.x.

AL ZAHRANI, A.W.; MOHAMED, A.H.; SERRANO JR, A.E.; TRAIFALGAR, R.F.M. Effects of feeding rate and frequency on growth and feed utilization efficiency in the camouflage grouper (Epinephelus polyphekadion) fingerlings fed a commercial diet. European Journal of Experimental Biology, v.3, p.596-601, 2013.

AYDIN, I.; KÜÇÜK, E.; ŞAHIN, T.; KOLOTOĞLU, L. The effect of feeding frequency and feeding rate on growth performance of juvenile black sea turbot (Psetta maxima, Linneaus, 1758). Journal of Fisheries Sciences, v.5, p.35-42, 2011.

BENETTI, D.D.; O'HANLON, B.; RIVERA, J.A.; WELCH, A.W.; MAXEY, C.; ORHUN, M.R. Growth rates of cobia (Rachycentron canadum) cultured in open ocean submerged cages in the Caribbean. Aquaculture, v.302, p.195-201, 2010. DOI: https://doi.org/10.1016/j.aquaculture.2010.02.021.

COSTA-BOMFIM, C.N.; PESSOA, W.V.N.; OLIVEIRA, R.L.M.; FARIAS, J.L.; DOMINGUES, E.C.; HAMILTON, S.; CAVALLI, $R$. The effect of feeding frequency on growth performance of juvenile cobia, Rachycentron canadum (Linnaeus, 1766). Journal of Applied Ichthyology, v.30, p.135-139, 2014. DOI: https://doi.org/10.1111/jai.12339.
CUNHA, V.L. da; SHEI, M.R.P.; OKAMOTO, M.H.; RODRIGUES, R.V.; SAMPAIO, L.A. Feeding rate and frequency on juvenile pompano growth. Pesquisa Agropecuária Brasileira, v.48, p.950-954, 2013. DOI: https://doi.org/10.1590/ S0100-204X2013000800020.

DITTY, J.G.; SHAW, R.F. Larval development, distribution, and ecology of cobia Rachycentron canadum (Family: Rachycentridae) in the northern Gulf of Mexico. Fishery Bulletin, v.90, p.668-677, 1992.

FABREGAT, T.E.H.P.; PEREIRA, T.S.; BOSCOLO, C.N.; ALVARADO, J.D.; FERNANDES, J.B.K. Substituição da farinha de peixe pelo farelo de soja em dietas para juvenis de curimba. Boletim do Instituto de Pesca, v.37, p.289-294, 2011.

KAUSHIK, S.J.; COVÈS, D.; DUTTO, G.; BLANC, D. Almost total replacement of fish meal by plant protein sources in the diet of a marine teleost, the European seabass, Dicentrarchus labrax. Aquaculture, v.230, p.391-404, 2004. DOI: https://doi.org/10.1016/S0044-8486(03)00422-8.

KERBER, C.E.; SANCHES, E.G.; SANTIAGO, M.; LUQUE, J.L. First record of Neobenedenia melleni (Monogenea: Capsalidae) in sea-farmed cobia (Rachycentron canadum) in Brazil. Revista Brasileira de Parasitologia Veterinária, v.20, p.331-333, 2011. DOI: https://doi.org/10.1590/S1984-29612011000400013.

MOREIRA, C.B.; ROMBENSO, A.N.; CANDIOTTO, F.B.; TSUZUKI, M.Y. Feeding frequency affects growth of juvenile cobia Rachycentron canadum cultured in near-shore cages. Boletim do Instituto de Pesca, v.41, p.219-226, 2015.

NHU, V.C.; NGUYEN, H.Q.; LE, T.L.; TRAN, M.T.; SORGELOOS, P.; DIERCKENS, K.; REINERTSEN, H.; KJØRSVIK, E.; SVENNEVIG, N. Cobia Rachycentron canadum aquaculture in Vietnam: recent developments and prospects. Aquaculture, v.315, p.20-25, 2011. DOI: https://doi.org/10.1016/j. aquaculture.2010.07.024.

OLIVEIRA, L.A.A.G.; ALMEIDA, A.M.; PANDOLFO, P.S.V.; SOUZA, R.M. de; FERNANDES, L.F.L.; GOMES, L.C. Crescimento e produtividade de juvenis de robalo-peva a diferentes temperaturas e taxas de alimentação. Pesquisa Agropecuária Brasileira, v.48, p.857-862, 2013. DOI: https://doi. org/10.1590/S0100-204X2013000800007.

OSTINI, S.; OLIVEIRA, I.R.; SERRALHEIRO, P.C.S.; SANCHES, E.G. Criação do robalo-peva (Centropomus parallelus) submetido a diferentes densidades de estocagem. Revista Brasileira de Saúde e Produção Animal, v.8, p.250-257, 2007.

RAMOS, F.M.; SANCHES, E.G.; FUJIMOTO, R.Y.; COTTENS, K.F.; CERQUEIRA, V.R. Crescimento de juvenis da garoupaverdadeira Epinephelus marginatus submetidos a diferentes dietas. Boletim do Instituto de Pesca, v.38, p.81-88, 2012.

RESLEY, M.J.; WEBB JR., K.A.; HOLT, G.J. Growth and survival of juvenile cobia, Rachycentron canadum, at different salinities in a recirculating aquaculture system. Aquaculture, v.253, p.398407, 2006. DOI: https://doi.org/10.1016/j.aquaculture.2005.08.023.

SALAMA, A.J. Effects of different feeding frequency on the growth, survival and feed conversion ratio of the Asian sea bass Lates calcarifer juveniles reared under hypersaline seawater of the Red Sea. Aquaculture Research, v.39, p.561-567, 2008. DOI: https://doi.org/10.1111/j.1365-2109.2007.01890.x. 
SAMPAIO, L.A.; TESSER, M.B.; WASIELESKY JUNIOR, W. Avanços da maricultura na primeira década do século XXI: piscicultura e carcinocultura marinha. Revista Brasileira de Zootecnia, v.39, p.102-111, 2010. Suplemento especial. DOI: https://doi.org/10.1590/S1516-35982010001300012.

SANCHES, E.G.; HERRERA, L.A.; SATO, L.Y.; BORGES, J.S.; MACHADO, T.M.; KUHNEN, V.V. Salted sardine residue to feed cobia: zootechnic advantages and histological responses. Boletim do Instituto de Pesca, v.45, e442, 2019. DOI: https://doi.org/10.20950/1678-2305.2019.45.1.442.

SANCHES, E.G.; OLIVEIRA, I. da R.; SERRALHEIRO, P.C. da S.; OSTINI, S. Cultivo do robalo-peva, Centropomus parallelus, em sistema de recirculação marinho. Arquivos de Ciências do Mar, v.44, p.40-46, 2011.

SANCHES, E.G.; SILVA, F. da C.; LEITE, J.R.; SILVA, P.K.A.; KERBER, C.E.; SANTOS, P.A. dos. A incorporação de óleo de peixe na dieta pode melhorar o desempenho da garoupaverdadeira Epinephelus marginatus? Boletim do Instituto de Pesca, v.40, p.147-155, 2014bA.
SANCHES, E.G.; SILVA, F. da C.; RAMOS, A.P.F.D'A. Viabilidade econômica do cultivo do robalo-flecha em empreendimentos de carcinicultura no Nordeste do Brasil. Boletim do Instituto de Pesca, v.40, p.577-588, 2014aB.

SANTOS, M.M.; CALUMBY, J.A.; COELHO FILHO, P.A.; SOARES, E.C.; GENTELINI, A.L. Nível de arraçoamento e frequência alimentar no desempenho de alevinos de tilápia-donilo. Boletim do Instituto de Pesca, v.41, p.387-395, 2015.

SHAFFER, R.V.; NAKAMURA, E.L. Synopsis of biological data on the cobia Rachycentron canadum (Pisces: Rachycentridae). [S.1.]: U.S. Department of Commerce, 1989. 32p. (NOAA Technical Report NMFS 82; FAO Fisheries Synopsis, 153).

SUN, G.; LIU, Y.; QIU, D.; YI, M.; LI, X.; LI, Y. Effects of feeding rate and frequency on growth performance, digestion and nutrients balances of Atlantic salmon (Salmo salar) in recirculating aquaculture systems (RAS). Aquaculture Research, v.47, p.176188, 2016. DOI: https://doi.org/10.1111/are.12480. 